\title{
ANALISIS KEBUTUHAN PENGEMBANGAN KURIKULUM PELATIHAN KOMPETENSI MICE BAGI GURU SMK USAHA PERJALANAN WISATA
}

\author{
Gita Mahardika Pamuji dan Asep Herry Hernawan \\ PPPPTK Bisnis dan Pariwisata - Kementerian Pendidikan dan Kebudayaan \\ e-mail: gita.mahardika@kemdikbud.go.id
}

\begin{abstract}
Abstrak
MICE (Meeting, Incentive, Conference dan Exhibition) merupakan kompetensi di bidang pengaturan even. Penelitian ini merupakan studi pendahuluan atas kesenjangan kompetensi guru SMK dalam Kompetensi MICE. Tujuan penelitian ini adalah untuk mengetahui kompetensi MICE yang dibutuhkan, materi yang sesuai dengan kompetensi, bagaimana strategi pembelajarannya dan bagaimana melakukan evaluasinya. Guna dikembangkan menjadi desain kurikulum pelatihan kompetensi MICE bagi guru yang sesuai dengan kebutuhan. Penelitian menggunakan pendekatan kualitatif dengan menggunakan metode Design and Development Research. Teknik pengumpulan data dalam penelitian ini menggunakan wawancara kepada praktisi, dosen/widyaiswara, serta pejabat pengelola pelatihan, angket yang disebarkan kepada guru SMK Pariwisata, studi literatur dan studi dokumentasi. Hasil penelitian, didapatnya kompetensi MICE yang sesuai dengan kebutuhan, SKKNI dan KKNI, terdiri dari kompetensi; 1) Menyeleksi Venue Kegiatan, 2) Mengatur pendaftaran tamu dalam suatu acara, 3) Menangani Keramaian, 4) Bekerjasama dengan Kolega dan Pelanggan, 5) Mengikuti Prosedur Kesehatan, Keselamatan dan Keamanan, 6) Mengelola Kegiatan Sponsorship, Materi disesuai dengan kompetensi tersebut dan strategi pembelajaran menggunakan; discovery learning, problem based learning dan project based learning. Penilaian dilakukan terhadap 3 ranah yaitu; sikap, pengetahuan dan keterampilan. Dari temuan data penelitian ini, guna meningkatan kompetensi MICE guru SMK, perlu dikembangkan desain kurikulum pelatihan kompetensi MICE bagi Guru SMK.
\end{abstract}

Kata Kunci: desain kurikulum pelatihan, Design and Development, pelatihan MICE

\section{NEEDS ANALYSIS TO DEVELOP TRAINING CURRICULUM OF MICE COMPETENCE FOR TOURISM VOCATIONAL TEACHERS}

\begin{abstract}
MICE (Meeting, Incentive, Conference, and exhibition) is a competence in setting an event. This study is a preliminary study on vocational teacher competencies gaps in MICE. The purpose of this study was to determine the competence of MICE required, the material, learning process and how to perform the evaluation. In order to develop a curriculum for teachers training in MICE. The study used a qualitative approach using the Design and Development Research. Data collection techniques using interviews with practitioners, lecturers, and training manager. A questionnaire distributed to Tourism vocational school teachers, literature and documentation study. The results, gained competencies in accordance with the requirements of SKKNI and KKNI, consisting of; 1) Selecting event Venue, 2) Crowd handling, 3) setting Event registration, 4) Following the Health, Safety, and Security procedure, 5) Manage Event Sponsorship, 6) Working with Colleagues and Customers. Materials adapted to these competencies and instructional strategies to use; discovery learning, problem-based learning and project-based learning. An assessment conducted on three domains; attitudes, knowledge, and skills. From the findings of the data, in order to increase MICE competence of Tourism vocational teachers, need to be developed a training curriculum design for vocational teachers in MICE competency.
\end{abstract}


Keywords: curriculum design, Design and Development, MICE Training

\section{PENDAHULUAN}

Banyak aspek yang bisa membangun peningkatan mutu pendidikan. Salah satu aspek yang penting dalam meningkatkan kualitas pendidikan adalah guru. Guru berada pada barisan terdepan dalam pelaksanaan pendidikan, yang langsung berhadapan dengan peserta didik untuk mentransfer ilmu pengetahuan dan teknologi sekaligus mendidik dengan nilainilai positif melalui bimbingan dan keteladanan. Peserta didik yang berkualitas menyeluruh dalam Sikap (Attittude), pengetahuan (knowledge) dan keterampilan (skill) dihasilkan oleh guru. Oleh karena itu, sosok guru yang mempunyai kualifikasi, kompetensi, dan dedikasi yang tinggi sangat diperlukan dalam menjalankan tugas profesionalnya.

Pendidikan dan pelatihan merupakan merupakan salah satu upaya dalam pengembangan kompetensi. Tujuan pendidikan dan pelatihan (diklat) pada dasarnya, untuk meningkatkan pengetahuan, sikap dan keterampilan bagi kepentingan individual dalam rangka mengembangkan pribadinya guna membantu penyelesaian pekerjaan. Salah satu yang bisa mewujudkan tujuan diklat adalah kurikulum diklat yang sesuai dengan jenis diklat dan kebutuhan peserta diklat agar tepat sasaran. Pendidikan biasanya mempersiapkan calon tenaga yang diperlukan oleh suatu instansi atau organisasi, sedangkan pelatihan merupakan peningkatan kemampuan atau keterampilan pegawai yang sudah menduduki suatu pekerjaan atau tugas tertentu. Penekanan pelatihan berorientasi pada tugas yang harus dilaksanakan (job orientation), menekankan kepada kemampuan psikomotor, meskipun didasari pengetahuan dan sikap sedangkan pendidikan lebih pada pengembangan kemampuan umum dan ketiga area (kognitif, afektif, dan psikomotor) memperoleh pengetahuan yang seimbang (Peraturan Pemerintah Nomor 101 tahun 2000, tentang Pendidikan dan Pelatihan Pegawai Negeri Sipil). Sudah seharusnya kurikulum pelatihan yang dikembangkan disesuaikan dengan kebutuhan pemenuhan kompetensi dari peserta didik. Kompetensi merupakan karakteristik dasar yang dimiliki setiap individu dimana karakteritik dasar tersebut berhubungan dengan kireja dengan kriteria baik atau unggul serta efektif dalam suatu pekerjaan dan situasi tertentu.

Bagaimanpun juga suatu pelatihan harus mempunyai kurikulum yang baik. Kurikulum adalah sebuah dokumen tertulis yang berisikan rancangan pembelajaran berisikan tujuan, isi/konten, metode/ proses/aktivitas dan evaluasi, untuk mencapai tujuan pendidikan tertentu, yang disusun dengan mempertimbangkan berbagai hal mengenai proses pembelajaran serta perkembangan individu.

MICE merupakan akronim dari Meeting, Incentive, Conference dan Exhibition, di Indonesia Istilah MICE ini menjadi populer dan lebih terkenal dengan istilah event. Perkembangan MICE sangat signifikan di Indonesia sendiri, untuk Meeting saja menurut laporan International Congress and Convention Association tahun 2016 terdapat 94 konferensi international dengan partisipan mencapai 41.350 orang, ini hanya dari segi konferensi atau meeting international, belum ditunjang dari pameran maupun incentive tour, baik skala nasional maupun internasional. Namun pendidikan mengenai MICE atau event ini masih belum bisa diidentifikasikan. Adanya gap antara industri dan pendidikan mengenai kompetensi yang harus dimiliki. Hal ini dikarenakan karena belum adanya pelatihan terhadap para pendidik. Para praktisi belum memiliki pendidikan yang mumpuni dan para pendidik kurang berkomunikasi dengan para praktisi. Pendidikan kurang memberikan penelitian dan pembelajaran yang berguna bagi para praktisi terutama dalam perancangan, produksi dan manajemen (Getz, 2007).

Hasil pemetaan UKG 2015, menggambarkan mengenai kompetensi 
yang dimiliki oleh guru SMK Usaha Perjalanan Wisata, dari 10 Kelompok Kompetensi yang diujikan, kelompok kompetensi MICE memiliki jumlah peserta UKG dengan nilai di bawah capaian kompetensi minimum paling banyak.

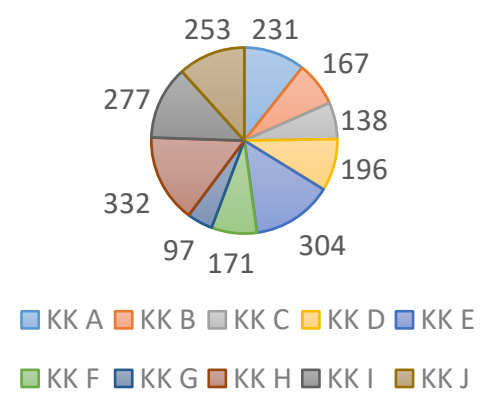

Gambar 1. Jumlah Peserta di bawah Capaian Minimum di 10 Kelompok Kompetensi Guru Usaha Perjalanan Wisata data hasil UKG 2015

Peserta UKG tahun 2015 berjumlah 473 peserta, untuk kelompok kompetensi $\mathrm{E}$ MICE, 304 orang peserta mendapatkan skore di bawah 55, yang merupakan capaian kompetensi minimum untuk UKG tahun 2015. Sedangkan untuk kelompok kompetensi H MICE dan Advance ticketing dari 374 peserta UKG tahun 2015, 332 orang peserta di bawah capaian kompetensi minimum. Hasil UKG 2015 pada kelompok kompetensi MICE menunjukan angka yang signifikan mengenai kurangnya pengetahuan mengenai kompetensi MICE di kalangan guru peserta UKG 2015.

Kompetensi MICE adalah kompetensi baru di SMK dan masih banyak guru yang belum mengetahui kompetensi ini, padahal guru harus sudah mengajarkan kompetensi ini kepada para peserta didiknya. Urgensi ini yang menimbulkan perlunya diidentifikasi kebutuhan diklat, untuk pengembangan desain kurikulum pelatihan kelompok kompetensi MICE bagi guru Sekolah Menengah Kejuruan bidang Pariwisata.

\section{METODE}

Penelitian ini menggunakan metode penelitian yang dikembangkan oleh Richey dan Klein (2009) yaitu Design and Development (DDR), atau penelitian desain dan pengembangan dengan pendekatan kualitatif. Partisipan dalam penelitian analisis kebutuhan pelatihan kompetensi MICE ini terdiri dari 2 kelompok. Kelompok pertama adalah guru, Guru yang dijadikan partisipan dalam penelitian pendahuluan adalah guru SMK usaha perjalanan wisata yang pernah mengikuti pelatihan Instruktur Nasional kompetensi di PPPPTK bisnis dan pariwisata yang diselenggarakan pada tahun 2015/2016 yang terdiri dari 2 angkatan pelatihan masing-masing pelatihan terdiri dari 20 orang peserta. Di mana data yang dihasilkan dari guru dikumpulkan dengan angket, untuk mengetahui pengetahuan awal mengenai kompetensi, materi strategi dan penilaian yang dibutuhkan untuk mengembangkan desain kurikulum pelatihan MICE bagi guru SMK UPW. Angket dibuat dalam bentuk daring (online) berupa google form di mana tautan dari google form tersebut nanti yang akan disebarkan kepada bapak ibu guru SMK.

Partisipan kelompok kedua adalah para narasumber dari industri, dosen, widyaiswara dan pejabat di PPPPTK bisnis dan pariwisata. Pengumpulan data menggunakan teknik wawancara. Dalam riset kualitatif wawancara mendalam (in-depth interview) merupakan salah satu teknik pengumpulan data utama (Ali, 2014; Fraenkel, Wallen, \& Hyun, 2012). Teknik ini diharapkan dapat menggali informasi secara seksama.

\section{HASIL DAN PEMBAHASAN Hasil}

Hasil wawancara dengan para praktisi dunia usaha dan dunia Industri, dapat disimpulkan bahwa kompetensi yang harus dimiliki oleh siswa SMK adalah kompetensi awal atau sifatnya operasional atau level bawahan belum masuk kepada kompetensi-kompetensi manajerial. Beberapa kompetensi awal seperti menangani keramaian, menginstal dan membongkar elemen pameran, memproses loading dan unloading, menangani staging, menangani 
lighting, menangani Audio Visual, memproses kegiatan pendaftaran dan menangani kegiatan protokoler merupakan kompetensi awal dari seorang pegawai operasional di bidang MICE, kompetensi yang disarankan adalah kompotensi yang masih berada di level 2 KKNI. Selain itu ada juga kompetensi pendukung seperti keselamatan dan keamanan kerja, bekerjasama dengan lingkungan sosial yang beragam, bekerja sama dengan kolega dan pelanggan, mengumpulkan dan menyajikan informasi, dan bahasa Inggris operasional. Kompetensi tersebut adalah kompetensi penunjang namun merupakan kompetensi yang harus dimiliki oleh setiap insan pariwisata. Kompetensi untuk guru harus lebih dari kompetensi yang dimiliki oleh siswa, dengan syarat utama guru harus sudah menguasai kompetensi yang dmiliki oleh peserta didiknya. Jika dicontohkan, kompetensi siswa SMK berada di level 2-3 KKNI, maka kompetensi guru harus berada di level 4 atau 5 dari KKNI, dengan syarat guru sudah menguasai kompetensi di level 2 dan 3. Para praktisi dunia usaha dan dunia industri menyampaikan untuk kepentingan pelatihan guru SMK, kompetensi yang bisa disampaikan dan diujikan sebaiknya dibuat berjenjang diawali dari kompetensi yang level 2 dan 3 agar guru bisa menyampaikan materi kepada siswanya dan jenjang berikutnya kompetensi di level 4 atau 5 . Akan tetapi salah satu praktisi menyampaikan tidak semua kompetensi MICE yang berada di level 4 atau 5 KKNI bisa atau harus dimiliki guru, harus disesuaikan dengan lingkungan sekolahnya. Artinya jika di lingkungan sekolahnya jarang dilakukan acara pameran, kompetensi mengembangkan strategi pada kegiatan pameran, dirasa tidak perlu dikuasai. Contoh lain adalah kompetensi melakukan negosiasi dengan vendor, untuk Guru SMK kompetensi melakukan negosiasi dengan vendor tidak terlalu penting untuk dikuasai, karena siswa SMK yang akan diajarnya tidak terlalu memerlukan kompetensi tersebut.

Materi atau isi dari kompetensi yang harus disampaikan selayaknya disesuaikan dengan kompetensinya masing-masing sesuai dengan SKKNI atau standar yang ada. Supaya pengetahuan dan keterampilan yang dimiliki oleh siswa bisa disesuaikan dengan keterampilan dan pengetahuan yang dibutuhkan oleh industri. Namun materimateri yang sudah mulai surut tapi justru penting harus mulai dimasukan lagi. Seperti materi handling complain, telephone courtesy, grooming (personal presentation) dan bekerjasama dalam tim.

Pembelajaran di industri, biasanya dilakukan dengan sistem coaching atau shadowing. Di mana trainee atau pegawai baru akan dititipkan untuk dilatih oleh para supervisor. Para supervisor atau rekan kerja bertanggung jawab dalam mentransfer product knowledge atau tugas kepada pegawai baru, maka dari itu salah satu kompetensi utama yang harus dimiliki adalah bagaimana siswa atau guru mempunyai kemampuan untuk bekerja sama dengan rekan sejawat atau kolega. Namun tetap saja pada awalnya harus disampaikan terlebih dahulu secara teoritis atau ceramah setelah itu didemonstrasikan, walau tidak dalam ruang kelas atau dalam pelatihan biasanya koleganya diminta untuk menunjukan bagaimana melakukan keterampilan tersebut.

Hasil wawancara dengan widyaiswara dan dosen, pada pertemuan pertama hasil wawancara belum menemukan kompetensi MICE apa saja yang sesuai dengan pelatihan yang akan diberikan kepada guru SMK pariwisata. Pertemuan pertama masih membicarakan mengenai di level berapakah KKNI guru itu berada, serta kompetensi level berapa yang harus atau bisa disampaikan. Hasil wawancara pada pertemuan pertama menghasilkan bahwa dalam pelatihan kompetensi MICE tidak bisa murni menggunakan satu level KKNI saja seperti yang disampaikan oleh narasumber lainnya, di mana Level KKNI pelatihan guru berada di level 4. Menurut pemahaman narasumber dosen bisa saja terdapat beberapa kompetensi di level yang lebih rendah atau bahkan yang lebih tinggi yang bisa dipelajari oleh peserta pelatihan. Narasumber menyarankan untuk meme- 
takan kompetensi berdasarkan hasil angket, wawancara, studi dokumentasi dan studi literasi. Kemudian melakukan wawancara lanjutan dengan para narasumber untuk memilih kompetensi mana saja yang bisa disampaikan dalam pelatihan MICE bagi guru SMK. Pada pertemuan kedua narasumber memutuskan 6 kompetensi yang bisa disampaikan kepada guru dalam pelatihan MICE. Kompetensi MICE yang dapat disampaikan dalam pelatihan MICE bagi guru SMK adalah 1) bekerja sama dengan kolega dan pelanggan; 2) menangani keramaian; 3) menyeleksi venue kegiatan; 4) mengikuti Prosedur kesehatan, keselamatan dan keamanan di tempat kerja; 5) menangani perijinan kegiatan; dan 6) mengelola kegiatan sponsorship.

Pembicaraan mengenai materi (konten) pelatihan berdasarkan SKKNI dosen yang bergerak di bidang Pariwisata dan pernah melakukan pelatihan untuk guru SMK di bidang pariwisata, terutama MICE ini, menyampaikan bahwa materi atau informasi yang dimiliki oleh para guru sangatlah minim, maka dibutuhkan penguatan di bidang materi. Materi-materi yang harus dikuatkan adalah materi awal seperti penjelasan mengenai jenis jenis dan tipe-tipe kegiatan yang berada dalam MICE. Materi dasar mengenai jenis meeting, incentive tour tour, conference dan exhibition harus diterapkan dengan pemahaman yang kuat, di mana perbedaan yang jelas dan penerapannya di kehidupan sehari-hari di lingkungannya masingmasing. Dalam pembicaraan mengenai konten/maupun materi dari kompetensi MICE, diharuskan diambil dari SKKNI. Dengan beberapa tambahan dan penyesuaian dengan kearifan daerah masing masing.

Pembelajaran vokasi memang menitikberatkan kepada pembiasaaan dan pembelajaran ranah keterampilan, namun berbeda dengan vokasi lainnya ranah keterampilan dalam kelompok kompetensi MICE menuntut keterampilan nalar atau pemikirian metakognitif. Bagaimana keterampilan dalam menganalisis strategi pasar, keterampilan dalam menggunakan media teknologi, atau mengkorelasikan antara even tertentu dengan penggunaan lighting, panggung, sarana promosi, pengaturan SDM eksternal maupun internal ataupun berkreatif dalam berbagai elemen suatu even. Proses pembelajaran yang menumbuhkan tidak hanya muscle memory akan tetapi penggunaan nalar yang harus diajarkan dan bahkan dilatih dan dibiasakan. Strategi pembelajaran yang bisa disampaikan tidak hanya Discovery learning, Inquiry, Problem based learning, atau project based learning. Sebuah pembiasaan dalam menemukan suatu permasalahan dan solusinya, atau membiasakan membuat projek dapat memicu kreatifitas para peserta pelatihan. Namun beberapa strategi dan metode pun dapat melahirkan kreatifitas seperti studi kasus, terutama jika kasus-kasus yang terkini, dalam kehidupan nyata, akan membantu penalaran dan pemahaman yang lebih bermakna.

Penilaian harus disesuaikan dengan kompetensi, bisa saja menggunakan tes lisan, tertulis, demonstrasi/praktek, dan mengadakan simulasi di tempat kerja atau workshop. Biasanya lembar observasi untuk unjuk kerja akan disesuaikan dengan kompetensinya, karena juga dapat berupa hasil produk. Untuk penilaian pengetahuan menggunakan pre dan post test, untuk penilaian sikap yang berupa observasi terhadap kedisiplinan keseharian atau sikap kerja ditunjukkan sesuai dengan kompetensi. Semisal untuk kompetensi pengaturan pendaftaran tamu maka sikap kerja yang ditunjukkan seperti tersenyum, teknik berdiri yang baik, greeting dan lain sebagainya.

Berdasarkan pemikiran bahwa lulusan SMK diharapkan terserap di dunia industri dan dunia usaha, serta guna mendukung Instruksi Presiden Nomor. 9 Tahun 2016 tentang Revitalisasi SMK. Maka dibuatkan 2 program pelatihan yaitu Keahlian ganda dan revitaliasi guru SMK. Untuk Program peningkatan kompetensi guru sesuai dengan revitalisasi SMK, dengan banyaknya ragam kompetensi keahlian yang ada di SMK memerlukan 
guru produktif yang memiliki kompetensi beragam pula. Untuk memenuhi kebutuhan dan kompetensi guru produktif, Ditjen GTK mengembangkan beberapa kegiatan mayor (utama) dan minor (pendukung) yang dilaksanakan pada tahun 2018 sampai tahun 2020. Program Revitalisasi SMK ini efektif untuk memenuhi dan meningkatkan kompetensi guru dan tenaga kependidikan. Peningkatan kompetensi guru secara intensif melalui pelatihan berbasis kompetensi, sertifikasi keahlian, dan diakhiri dengan implementasi di sekolah dapat menghasilkan guru yang memiliki kompetensi keahlian tertentu sesuai dengan tuntutan DU/DI dan mengacu pada KKNI Level IV.

Angket disebar ke 40 orang guru di seluruh penjuru Indonesia. Guru yang menerima angket adalah guru yang pernah mengikuti pelatihan Usaha Perjalanan Wisata, pada tahun 2015-2016. Dari 40 orang guru partisipan penelitian, 34 angket diterima kembali oleh peneliti. Angket yng tersebar hampir mewakili masing-masing provinsi di Indonesia.

Angket yang disebar berisikan pertanyaan mengenai, kompetensi MICE guru, materi mengenai kompetensi MICE yang dibutuhkan oleh guru, bagaimana pembelajaran yang sesuai untuk mengajarkan kompetensi MICE dan bagaimana kompetensi tersebut sebaiknya dinilai.

Dari sebaran partisipan penelitian, 16 orang berlatar belakang pendidikan S1/DIV pariwisata dan 13 orang berlatar belakang pendidikan S1/DIV Pendidikan, 6 orang dengan gelar Magister Pariwisata dan 2 orang bergelar Magister Pendidikan. 58,8 $\%$ partisipan penelitian yang mengisi angket sudah menjadi guru selama 5-10 tahun, dan 38,2 \% lebih dari 10 tahun. 79,4 $\%$ dari partisipan guru adalah Pegawai Negeri Sipil, sisanya gabungan dari Guru tetap yayasan, dan guru tidak tetap baik sekolah daerah maupun yayasan. Dan dari ke 34 partisipan $61,4 \%$ sudah tersertifikasi guru.
Tabel 1. Sebaran angket penelitan

\begin{tabular}{lccccc}
\hline \multirow{1}{*}{$\begin{array}{c}\text { Asal } \\
\text { Sekolah }\end{array}$} & $\begin{array}{c}\text { Jumlah } \\
\text { partisipan }\end{array}$ & \multicolumn{2}{c}{$\begin{array}{c}\text { Status } \\
\text { Pekerjaan }\end{array}$} & \multicolumn{2}{c}{ Serifikasi Guru } \\
& PNS & GTT & Belum & Sudah \\
\hline Sumatera & 10 & 7 & 3 & 4 & 6 \\
Jawa & 11 & 9 & 2 & 7 & 4 \\
Bali, NTB & 6 & 5 & 1 & 4 & 2 \\
dan NTT & 6 & 5 & 1 & 5 & 1 \\
Sulawesi & 1 & 1 & - & 1 & - \\
Kalimantan & 34 & 27 & 7 & 21 & 13 \\
Jumlah & & & & & \\
\hline
\end{tabular}

Data hasil angket ditemukan sebaran kompetensi yang dianggap penting untuk dipelajari oleh peserta pelatihan (guru). Kompetensi MICE tersebut adalah (diurutkan dari kompetensi yang paling penting): 1) Menyeleksi Venue Kegiatan; 2) Mengatur pendaftaran tamu dalam suatu acara; 3) Menangani kegiatan protokoler; 4) Menangani keramaian; 5) Menangani kegiatan acara protokoler; 6) Memproses pendaftaran tamu dalam suatu acara; 7) Mengatur dan mengawasi instalasi pembongkaran; dan 8) Mengawasi loadingunloading.

Selain 8 kompetensi di atas yang merupakan kompetensi utama kelompok keahlian MICE, terungkap beberapa data kompetensi tambahan yang dirasa penting untuk dikuasai oleh para guru. Kompetensi yang dirasa penting tidak hanya kompetensi mengenai kelompok kompetensi MICE yang berada di level KKNI 4 akan tetapi kompetensi MICE yang berada di level KKNI di atasnya yaitu di level 5. Serta beberapa kompetensi penunjang yang menurut guru penting dimiliki karena menjadi dasar dari kompetensi kepariwisataan. Kompetensi-kompetensi tersebut adalah: 1) Mengelola kegiatan sponshorship; 2) Bekerjasama dengan kolega; 3) Mengikuti prosedur K3; 4) Bidding proposal.

Seluruh partisipan (100\%) setuju bahwa kompetensi guru SMK sekarang belum sesuai dengan kompetensi MICE di SKKNI, hal ini disebabkan karena kurangnya pelatihan. Sehingga guna memenuhi kesenjangan kompetensi tersebut para partisipan menyarankan 
kepada pemerintah untuk menyelenggarakan program pelatihan MICE. Selanjutnya guru mencari informasi secara mandiri dan melakukan magang di dunia usaha maupun dunia industri. Dari hasil angketpun diketahui bahwa kompetensi untuk Guru yang sesuai dengan SKKNI dan KKNI adalah level 4 (70,4 \%).

Konten atau materi tertinggi dari kompetensi yang harus disampaikan adalah kompetensi mengatur pendaftaran tamu dan dilanjutkan dengan menyeleksi vепие, menangani keramaian dengan beberapa materi tambahan yang dirasa penting seperti; Bidding poposal, sponsorship, dan bekerja sama dengan kolega.

Hasil sebaran angket mengenai model pembelajaran yang sesuai dengan karakteristik kompetensi MICE, Project based learning menjadi pilihan utama model pembelajaran yang digunakan dalam pembelajaran dan penyampaian informasi kepada peserta Pelatihan. Selain projectbased learning guru pun mengkombinasikan dengan problem based learning dan discovery learning. Selain ketiga hal tersebut dalam proses pembelajaran bisa menggunakan beberapa teknik atau strategi seperti melakukan bermain peran atau demonstrasi, bisa juga dengan beberapa projek membuat even kecil, atau studi kasus. Cara lain penyampaian materi adalah dengan magang di dunia usaha/dunia industri, kunjungan industri dan coaching clinik. Sedangkan cara paling efisien dalam melakukan pembelajaran kompetensi MICE dengan praktek langsung sebagai contoh dengan mengadakan studi kasus tertentu dan atau dengan diskusi dan unjuk kerja.

Penilaian yang dilakukan untuk kompetensi MICE lebih menekankan kepada penilaian observasi untuk sikap. Penilaian menggunakan tes tertulis untuk pengetahuan dan penilaian proyek dan unjuk kerja untuk keterampilan.

Data angket mengungkapkan bahwa pelaksanaan pelatihan berkisar 70-100 jam pelajaran saja, dan menggunakan bentuk pelatihan kombinasi daring dengan tatap muka. Dan waktu yang tepat untuk dilaksanakan kegiatan pelatihan adalah bulan Agustus (9,4\%), bertempat di PPPPTK Bisnis dan Pariwisata (68\%).

\section{Pembahasan}

Disiplin ilmu MICE kurang diapresiasi di dunia pendidikan karena dianggap sebagai profesi yang tidak umum dan hanya bagian kecil dari bisnis pariwisata (Sperstad \& Cecil, 2011). MICE merupakan suatu rangkaian kegiatan, di mana para pengusaha atau professional berkumpul pada suatu tempat yang terkondisikan oleh suatu permasalahan, pembahasan, atau kepentingan yang sama (Oka A. Yoeti, 2000). MICE adalah suatu kegiatan kepariwisataan yang aktivitasnya merupakan perpaduan LEASURE dan BUSINESS, biasanya melibatkan sekelompok orang yang secara bersama-sama. Rangkaian kegiatan dalam bentuk Pertemuan, Insentif, Konvensi, dan Pameran (Meeting, Incentive, Convention, and Exhibition) (Indrajaya, 2015; Kesrul, 2004). Penekanan kepada pemahaman jenis dan bentuk kegiatan usaha MICE menjadi sangatlah penting, bagaimana membumikan istilah MICE menjadi mudah dipahami oleh peserta pelatihan (Pamuji, 2015).

Hasil dari wawancara dan angket maka dapat disimpulkan bahwa kurikulum pelatihan kelompok kompetensi MICE menentukan kompetensi yang disampaikan, materi untuk pemenuhan kompetensi tersebut, proses pembelajaran atau metode penyampaian materi selama kegiatan pelatihan berlangsung, dan penilaian (evaluasi) yang sesuai dengan kompetensi di atas.

Kelompok kompetensi MICE memanglah bukan hal yang baru di dunia pariwisata, namun untuk di Indonesia, di bidang akademisi, dan disiplin ilmu masih merupakan sesuatu yang baru. Disiplin ilmu MICE kurang diapresiasi di dunia pendidikan karena dianggap sebagai profesi yang tidak umum dan hanya bagian kecil dari bisnis pariwisata (Sperstad \& Cecil, 2011), namun beberapa mulai mengembangkan kurikulum MICE (Hsieh, 2013). Pentingnya kompetensi MICE digambarkan dalam suatu sistem yang rumit dimana di- 
pengaruhi oleh berbagai pihak. Peran stakeholder, vendor (hotel, restoran, transportasi, venue) atau dunia industri sangat berpengaruh agar para peserta didik mampu mengikuti keterampilan yang diharapkan industri dan tentunya pemerintah harus ikut mendorong berkembangnya industri MICE, pendidikan di bidang MICE serta peraturan penunjang mengenai kompetensi yang dibutuhkan (Junaedi, 2016; Morgan, 2004; Smith \& Cooper, 2000; Tribe, 2002). Bagaimanapun juga industri MICE akhir-akhir ini memberikan berbagai manfaat secara ekonomis bagi tempat diselanggarakannya suatu even MICE dan menuntut timbulnya profesi-profesi baru di bidang MICE, maka dari itu perkembangan dari segi ekonomi dan sumber daya manusia pendukung industri MICE tersebut menuntut MICE menjadi suatu disiplin ilmu, dan dibutuhkan suatu pondasi akademik yang kuat untuk para praktisi agar lebih profesional (Getz, 2007). Selain itu beberapa kompetensi dalam bidang event (MICE) dibagi menjadi administrasi, desain, marketing, operational dan Risk management (J. Silvers, Bowdin, O'Toole, \& Nelson, 2006). Kompetensi MICE yang harus disampaikan dalam pelatihan MICE ke guru SMK Usaha Perjalanan Wisata berada di level 4 KKNI (Direktorat PSMK, 2017). Namun beberapa narasumber ahli menyampaikan:

“...dalam pelatihan kompetensi MICE tidak bisa murni menggunakan satu level, bisa saja terdapat beberapa kompetensi di level yang lebih rendah atau bahkan yang lebih tinggi yang bisa dipelajari oleh peserta pelatihan" (narasumber Dosen).

"...sebaiknya dibuat berjenjang diawali dari kompetensi yang level 2 dan 3 agar guru bisa menyampaikan materi kepada siswanya dan jenjang berikutnya kompetensi di level 4 atau 5" (Narasumber Praktisi Dunia Usaha /Dunia Industri).
- “...Kompetensi yang sesuai dengan pelatihan peningkatan kompetensi para guru, untuk kompetensi keahlian MICE adalah kompetensi yang utama MICE dan penunjang kompetensi MICE yang sesuai dengan SKKNI yang beraaa di level IV KKNI" (narasumber Widyaiswara)

Kompetensi MICE yang diberikan kepada peserta pelatihan adalah kompetensi MICE yang terdapat di SKKNI dan di level IV KKNI berupa: 1) Menyeleksi venue kegiatan; 2) Mengatur pendaftaran tamu dalam suatu acara; 3) Menangani keramaian; 4) Bekerja sama dengan kolega dan pelanggan; 5) Mengikuti Prosedur kesehatan, keselamatan dan keamanan di tempat kerja; dan 6) Mengelola kegiatan sponsorship.

Ke-enam kompetensi ini bukan merupakan kompetensi utuh di level 4 KKNI namun memiliki kompetensi penunjang yang dirasa oleh para narasumber sangat dibutuhkan terutama untuk memberikan pengajaran terhadap peserta didiknya di SMK.

\section{Materi Pelatihan (konten)}

Materi ataupun konten dalam desain kurikulum pelatihan kompetensi MICE bagi guru SMK Usaha Perjalanan Wisata terdiri dari Materi Kompetensi MICE dan materi Penunjang atau materi kepariwisataan, yang disesuaikan dengan kompetensi sebagai tujuan pembelajaran. Penekanan kepada pemahaman jenis dan bentuk kegiatan usaha MICE menjadi sangatlah penting, bagaimana membumikan istilah MICE manjadi mudah dipahami oleh peserta pelatihan (Pamuji, 2015). Bisnis MICE merupakan bisnis jasa kepariwisataan yang bergerak di seputar Pertemuan, Insentif, Konvensi, dan Pameran (Meeting, Incentive, Convention, and Exhibition), suatu jenis pariwisata di mana suatu kelompok besar, biasanya direncanakan dengan matang, untuk tujuan tertentu (Indrajaya, 2015). updating pengetahuan dalam materi tertentu seperti manajemen resiko. Salah satu materi manajemen resiko adalah penanganan 
keramaian (crowd control) di mana penanganan keramaian harus memper hatikan visitor behaviours dan tipologi, selain itu pemahaman akan perizinan, legal, dan pihak otoritas yang terkait harus terus di update (Säterhed et al., 2011; J. R. Silvers, 2008). Seperti yang disampaikan oleh salah satu narasumber ahli di bawah ini:

- "...Materi dasar mengenai jenis meeting, incentive tour tour, conference dan exhibition harus di terapkan dengan pemahaman yang kuat, dimana perbedaan yang jelas dan penerapannya di kehiduan sehari-hari dilingkungannya masingmasing" (narasumber Dosen)

- “...materi - materi yang penting sebagai cirikhas insan pariwisata seperti halnya materi wawasan pengenalan budaya bangsa, keberagaman, komunikasi efektif (public relation), dan attitude dalam berpariwisata (personal grooming, personal presentation, greeting, senyum)" (narasumber Dosen).

Cara berpakaian merupakan salah satu elemen dalam personal presentation, dengan berpakaian yang sesuai secara profesional dapat memberikan kepercayaan diri yang secara tidak langsung ditunjukan kepada orang lain melalui sikap dan tindakan, dan terkadang satu jenis pakaian atau asesoris dapat menunjukan pekerjaan maupun jabatan seseorang dalam suatu profesi (Joel \& Kasamba, 2014; Rasband, n.d.).

Tabel 2. Materi pokok kompetensi MICE sesuai kompetensi

\begin{aligned} \hline No & \multicolumn{1}{c}{ Kompetensi } \\ \hline 1. & $\begin{array}{l}\text { Menyeleksi Venue } \\ \text { Kegiatan }\end{array} \\$ 2. & $\begin{array}{l}\text { Mengatur pendaftaran } \\ \text { tamu dalam suatu acara }\end{array}\end{aligned}$

3. Menangani Keramaian

4. Bekerjasama Dengan Kolega dan Pelanggan
1.1. Konteks dan jenis kegiatan

1.2. Kebutuhan terkait sifat dan jenis kegiatan

1.3. Spesifikasi venue

1.4. Informasi yang dibutuhkan terkait venue

1.5. Sumber-sumber informasi terkait venue

1.6. Faktor-faktor yang penting dalam melakukan site inspection

1.7. spesifikasi dari kegiatan pihak-pihak yang terkait dalam site inspection

2.1. Data based dan peralatan yang diperlukan

2.2. Persiapan tempat pendaftaran

2.3. Perincian aksesibilitas (handicap)

2.4. Signage dan rambu rambu

2.5. Materi pendaftaran

2.6. Prosedur pendaftaran

2.7. Penangan ketidakcocokan data

3.1. Identifikasi jenis kegiatan

3.2. Jenis penanganan keramaian

3.3. Sumber daya internal dan eksternal

3.4. Administrasi kebutuhan

3.5. Tindakan yang dianggap perlu

3.6. Evaluasi kegiatan

3.7. Laporan penangan keramaian

4.1. Berkomunikasi di tempat kerja

4.2. Bantuan tamu internal maupun eksternal

4.3. Standar presentasi personal

4.4. Bekerjasama dalam tim 


\begin{tabular}{cll}
\hline No & \multicolumn{1}{c}{ Kompetensi } & \multicolumn{1}{c}{ Materi } \\
\hline 5. & Mengikuti Prosedur & 5.1. Prosedur kesehatan, keselamatan dan keamanan \\
& Kesehatan, Keselamatan & 5.2. Situasi darurat \\
dan Keamanan di & 5.3. Presentasi Personal sesuai dengan kebutuhan dan \\
Tempat Kerja & \multicolumn{1}{c}{ keselamatan kerja } \\
6. Mengelola Kegiatan & 4.1. Materi dan aktivitas yang disponsorkan \\
& 4.2. Potensi sponsor \\
& 4.3. Paket sponsor \\
& 4.4. Informasi mengenai kesempatan sponsor \\
& 4.5. Kontrak/perjanjian \\
& 4.6. detail pelaksanaan sponsor \\
& 4.7. Analisis perubahan \\
& 4.8. Timbal balik ker ja s ama \\
& 4.9. Evaluasi perjanjian \\
\hline
\end{tabular}

\section{Strategi Pembelajaran (metode)}

Proses pembelajaran merupakan suatu sistem di mana perancangan atau rencana pembelajaran perlu memperhatikan tata cara suatu sistem berjalan, Dengan demikian tujuan program dapat tercapai dengan efektif dan efesien (Kemp, 1994). Salah satu penentu dari pengambilan keputusan untuk menentukan strategi pembelajaran adalah karakteristik peserta, jika dilihat dari karakteritik 34 guru partisipan, $60 \%$ guru berpengalaman bekerja 5-10 tahun. Hal ini bisa dimaknai bahwa peserta pelatihan merupakan guru berpengalaman.

Perencanaan pembelajaran orang dewasa berbeda dengan peserta didik disekolah. Pendidikan orang dewasa di sebut sebagai andragogik menurut penelitian Malcolm Knowles pada akhir 1960-an (Knowles, 1980). Knowles memahami melalui penelitiannya bahwa para instruktur perlu memahami apa yang diinginkan oleh peserta pelatihan bukan berfokus kepada kebutuhan peserta pelatihan menurut keyakinan para instruktur (Carlson, 1989). Salah satu asumsi Knowles adalah setiap orang dewasa membawa pengalaman sendiri yang beragam ke dalam proses pembelajaran dalam pelatihan, sehingga menghasilkan gaya belajar, self exposure, dan gaya hidup yang berbeda pula. Berdasarkan perbedaan pengalaman yang dimilikinya, maka dalam sebuah pelaksanaan pelatihan orang dewasa akan saling bertukar pengetahuan antara satu dengan lainnya (Solfema, 2013; Yuse, Jamaris, \& Ismaniar, 2018).

Dalam menetapkan materi dan teknik pembelajaran untuk orang dewasa, materi lebih ditekankan pada pengalaman nyata, disesuaikan dengan kebutuhan dan berorientasi pada aplikasi praktis, sedangkan metode dan teknik harus menghindari teknik yang bersifat pemindahan pengetahuan dari fasilitator kepada peserta didik, harus lebih bersifat partisipatif (Sunhaji, 2013).

Sejalan dengan dengan itu beberapa narasumber ahli menyampaikan dalam wawancaranya:

- “...Pembelajaran di industri, biasanya dilakukan dengan sistem coaching atau shadowing, di mana trainee atau pegawai baru akan dititipkan untuk diberikan contoh, dilatih dan diminta untuk mempraktekannya dan diawasi oleh para supervisor" (narasumber Praktisi Dunia usaha/dunia industri)

- “...Meninjau karakteritik materi dan peserta pelatihan strategi pembelajaran aktif bisa digunakan seperti halnya discovery learning, Problem Based Learning bahkan Project-Based Learning yang disesuaikan dengan waktu pelatihan" (Narasumber Widyaiswara).

Maka dari itu untuk pembelajaran orang dewasa dibutuhkan pembelajaran 
aktif, pembelajaran yang melatih peserta didik untuk lebih aktif adalah pembelajaran induktif (Prince \& Felder, 2007). Pembelajaran induktif terdiri dari beberapa model yang meliputi: discovery learning, inquiry learning, problem-based learning, project-based learning, case-based learning, dan just-in-time teaching (Winarni, Santosa, \& Ramli, 2016).

\section{Penilaian (evaluasi)}

Dari hasil angket dan wawancara penilaian dilakukan terhadap 3 ranah yaitu sikap, pengetahuan dan keterampilan. Penilaian atau evaluasi merupakan komponen kurikulum yang digunakan untuk melihat keefektifan pencapaian tujuan baik itu kurikulum maupun pembelajaran. Evaluasi bisa berfungsi sumatif maupun formatif, evaluasi formatif adalah evaluasi yang dilakukan selama proses pembelajaran berlangsung dan bisa digunakan untuk memperbaiki pembelajaran berikutnya, sedangkan evaluasi sumatif adalah evaluasi yang dilakukan di akhir pembelajaran (Gagne, Briggs, \& Wager, 1992). Evaluasi sebagai alat ukur keberhasilan dalam mencapai tujuan. Evaluasi dapat dikelompokan menjadi 2 jenis yaitu evaluasi tes dan evaluasi non tes (Tim Pengembang MKDP, 2011). Aspek yang dinilai dalam pelatihan mencakup pengetahuan, sikap, dan keterampilan, Penilaian dilakukan melalui tes untuk aspek pengetahuan, dan menggunakan instrumen nontes melalui pengamatan selama kegiatan berlangsung untuk aspek sikap dan keterampilan, dengan menggunakan format-format penilaian yang telah disediakan (Direktorat Jendral Guru dan Tenaga Kependidikan, 2017).

\section{PENUTUP}

Dari hasil penelitian terhadap 34 guru SMK usaha perjalanan wisata dan wawancara terhadap 4 narasumber ahli, diketahui bahwa kompetensi yang dibutuhkan untuk melatih kompetensi MICE bagi guru SMK adalah; 1) Menyeleksi Venue kegiatan, 2) Mengatur pendaftaran tamu dalam suatu acara, 3)
Menangani Keramaian, 4) Bekerjasama dengan Kolega dan Pelanggan, 5) Mengikuti Prosedur Kesehatan, Keselamatan dan Keamanan, 6) Mengelola Kegiatan Sponsorship, Materi disesuaikan dengan kompetensi tersebut sesuai SKKNI dan ditambahkan beberapa pengkinian mengenai materi terbaru, strategi pembelajaran menggunakan; discovery learning, problem-based learning dan project-based learning dengan beberapa penyesuaian. Penilaian dilakukan terhadap 3 ranah yaitu; sikap, pengetahuan dan keterampilan dengan instrumen yang disesuaikan.

Hasil dari penelitian ini mengindikasikan bahwa dibutuhkan pengembangan desain kurikulum kelompok kompetensi MICE bagi guru Sekolah Menengah Kejuruan paket keahlian Usaha Perjalanan Wisata.

\section{UCAPAN TERIMA KASIH}

Ucapan terimakasih disampaikan kepada para narasumber ahli dari pihak dunia Industri dan dunia Usaha, narasumber dan narasumber Widyaiswara, Narasumber Pejabat kepala seksi program di PPPPTK bisnis dan Pariwisata Serta Kepala Pusat PPPPTK Bisnis dan Pariwisata.

\section{DAFTAR PUSTAKA}

Ali, M. (2014). Memahami Riset Perilaku dan Sosial. (Y. S. Hayati, Ed.). Jakarta: PT. Bumi Aksara.

Carlson, R. (1989). Malcolm Knowles: Apostle of andragogy. Vitae Scholasticae, 8(Springs).

Direktorat Jendral Guru dan Tenaga Kependidikan. (2017). Petunjuk Teknis Program Sertifikasi Pendidik Dan Sertifikasi Keahlian Bagi Guru Smk/Sma (Keahlian Ganda). Jakarta.

Direktorat PSMK. (2017). Pedoman Revitalisasi SMK. Jakarta: Direktorat Jenderal Guru dan Tenaga Kependidikan, Kementerian Pendidikan dan Kebudayaan.

Fraenkel, J. R., Wallen, N. E., \& Hyun, H. H. (2012). How to Design and Evaluate Research in Education. 
New York: TheMcGraw-Hill Companies, Inc.

Gagne, R. M., Briggs, L. J., \& Wager, W. W. (1992). Principles of Instructional Design (4th ed.). USA: Harcourt Brace College Publishers.

Getz, D. (2007). Event Studies: Theory, Reaserdch and Policy for Planned Event (first edit). Burlington: Elsevier Ltd.

Hsieh, P. F. (2013). Curriculum planning of MICE course in continuing education. Journal of Hospitality, Leisure, Sport and Tourism Education, 13(1), 107-122. https://doi.org/10.1016/j.jhlste.2013. 08.002

Indrajaya, T. (2015). Potensi Industri Mice (Meeting, Incentive, Conference And Exibition) Di Kota Tangerang Selatan, Provinsi Banten. Jurnal Ilmiah WIDYA, 3(Sepember), 80-87.

Joel, C., \& Kasamba, C. (2014). Communication of Gender through Personal Grooming and adornment in Different Cultures and different Times. International Journal of Scientific and Reasearch Publications, 4(10), 1-4.

Junaedi. (2016). Strategi pengembangan bisnis mice untuk mewujudkan kota surakarta sebagai kota mice. Hotelier Journal, 1(Juni).

Kemp, J. E. (1994). Proses Perancangan Pengajaran. Bandung: Penerbit ITB Bandung.

Kesrul, M. (2004). Meeting, Incetives, Converence and Exebition. Yogyakarta: Graha Ilmu.

Knowles, M. S. (1980). The modern practice of adult education: From pedagogy to andragogy. Chicago: Follet.

Morgan, M. (2004). From Production Line to Drama School: Higher Education for the Future of Tourism. Inter. J. Contemp. Hospitality., 16(2), 91-99.

Oka A. Yoeti. (2000). Manajemen Wisata Konvensi. Jakarta: Pertja.

Pamuji, G. M. (2015). Modul Kelompok Kompetensi E Pengelolaan MICE.
Jakarta: Kementerian Pendidikan dan Kebudayaan.

Prince, M., \& Felder, R. (2007). The Many Faces Of Inductive Teaching and Learning. Journal of College Science Teaching, 36(5).

Rasband, J. (n.d.). Power of Personal Appearance. Retrieved June 13, 2018, from

https://www.ldsbc.edu/documents/ca reer_services/Interviewing/Power of Personal Appearance.pdf

Richey, R. C., \& Klein, J. D. (2009). Design and Development Reaserch. New York: Routledge.

Säterhed, P., Hanson, M., Strandlund, J., Nilsson, T., Nilsson, D., Locken, M., \& Meimermondt, A. (2011). Event Safety Guide 2011. Swedish Civil Contingencies Agency.

Silvers, J., Bowdin, G., O'Toole, W., \& Nelson, K. (2006). Towards an international Event Management Body of Knowledge (EMBOK). Journal of Event Management, 9(4), 185-198.

Silvers, J. R. (2008). Risk Management for Meetings and Events. Burlington: Elsevier Ltd. All.

Smith, G., \& Cooper, C. (2000). Competitive Approaches to Tourism and Hospitality Curriculum Design. Journal of Travel Research, 39(1), 90-95.

https://doi.org/10.1177/00472875000 3900112.

Solfema. (2013). Andragogi Konsep dan Penerapannya. malang: Wineka Cipta.

Sperstad, J., \& Cecil, A. K. (2011). Changing Paradigm of Meeting Management: what does this mean for academia? Journal of Convention and Event Tourism, 12(4), 313-324.

Sunhaji. (2013). Konsep Pendidikan Orang Dewasa. Jurnal Kependidikan, 1(1), 1-11.

Tim Pengembang MKDP. (2011). Kurikulum dan Pembelajaran. Bandung: Raja Grafindo Persada.

Tribe, J. (2002). The Philosophic 
Practitioner. Tourism Res, 29(2), 338-357.

Winarni, Santosa, S., \& Ramli, M. (2016).

Discovery Learning Model for

Enhancing Oral Activities of High

School Student. BIOEDUKASI, 9(2), 55-61.

https://doi.org/10.20961/bioedukasiuns.v9i2.4220.

Yuse, A. P., Jamaris, \& Ismaniar. (2018).
Penerapan Pembelajaran Orang Dewasa Oleh Instruktur Pelatihan Keterampilan Menjahit di SPNF SKB Lima Puluh Kota. Spektrum PLS Jurnal Pendidikan Luar Sekolah, 1(1). https://doi.org/10.5281/zenodo.1186 395.

Appendix a.

Sebaran Angket Analisis Kebutuhan Pengembangan Kurikulum Pelatihan Kompetensi MICE (Meeting, Incentive, Conference dan Exhibition) bagi Guru Sekolah Menengah Kejuruan Usaha Perjalanan Wisata

\begin{tabular}{|c|c|c|c|c|c|}
\hline Asal Sekolah & Pendidikan & $\begin{array}{c}\text { Lama } \\
\text { Bekerja }\end{array}$ & $\begin{array}{c}\text { status } \\
\text { pekerjaan }\end{array}$ & $\begin{array}{c}\begin{array}{c}\text { Sertifikasi } \\
\text { Guru }\end{array} \\
\end{array}$ & $\begin{array}{c}\text { Jenis } \\
\text { kelamin }\end{array}$ \\
\hline $\begin{array}{l}\text { SMKN } 1 \text { Takengon - } \\
\text { Aceh Tengah }\end{array}$ & S2 (M.Par) & $5-10$ tahun & PNS & Belum & Pria \\
\hline SMKN 3 Lhokseumawe & DIV (SST.Par) & $5-10$ tahun & $\begin{array}{l}\text { guru } \\
\text { honorer/GHS/ } \\
\text { GTT }\end{array}$ & Belum & Wanita \\
\hline SMKN 1 Medan & S2 (M.Par) & $>10$ tahun & PNS & Belum & Wanita \\
\hline SMKN 1 Lingsar & DIV (SST.Par ) & $5-10$ tahun & $\begin{array}{l}\text { pegawai } \\
\text { swasta/yayasa } \\
\text { n/GTY }\end{array}$ & Sudah & Wanita \\
\hline SMKN 2 Pariaman & S2 (M.Par) & 5 - 10 tahun & PNS & Belum & Wanita \\
\hline SMKN 2 Kota Jambi & DIV (SST.Par ) & 5 - 10 tahun & PNS & Belum & Wanita \\
\hline SMKN 1 Tanjung Pinang & S1 (S.Pd ) & $>10$ tahun & PNS & Sudah & Pria \\
\hline SMKN 1 Kota Bengkulu & $\mathrm{S} 1$ (S.Pd ) & $>10$ tahun & PNS & Sudah & Pria \\
\hline SMKN 1 Dumai & DIV (SST.Par ) & $>10$ tahun & $\begin{array}{l}\text { guru } \\
\text { honorer/GHS/ } \\
\text { GTT }\end{array}$ & Sudah & Wanita \\
\hline $\begin{array}{l}\text { SMKN } 3 \text { Bandar } \\
\text { Lampung }\end{array}$ & S1 (S.Pd ) & $>10$ tahun & PNS & Belum & Wanita \\
\hline SMKN 33 Jakarta & DIV (SST.Par ) & $>10$ tahun & PNS & Sudah & Pria \\
\hline SMKN 1 Pacet & DIV (SST.Par ) & 5 - 10 tahun & PNS & Sudah & Pria \\
\hline SMKN 1 Kota Bandung & DIV (SST.Par ) & $>10$ tahun & PNS & Sudah & Wanita \\
\hline SMKN 3 Kota Bandung & DIV (SST.Par ) & 5 - 10 tahun & $\begin{array}{l}\text { guru } \\
\text { honorer/GHS/ } \\
\text { GTT }\end{array}$ & Belum & Wanita \\
\hline SMKN 4 Yogyakarta & S1 (S.Pd ) & $5-10$ tahun & PNS & Sudah & Wanita \\
\hline SMKN 4 Yogyakarta & S1 (S.Pd ) & 5 - 10 tahun & PNS & Belum & Pria \\
\hline SMKN 1 Selo & S2 (M.Par) & $>10$ tahun & PNS & Sudah & Wanita \\
\hline SMKN 1 Selo & S1 (S.Pd ) & $>10$ tahun & PNS & Sudah & Wanita \\
\hline SMKN 1 Malang & $\begin{array}{l}\text { S1 (S.Pd); DIV } \\
\text { (SST.Par) }\end{array}$ & $>10$ tahun & PNS & Sudah & Wanita \\
\hline SMK Putikecwara Batu & S2 (M.Par) & $5-10$ tahun & $\begin{array}{l}\text { pegawai } \\
\text { swasta/yayasa } \\
\text { n/GTY }\end{array}$ & Belum & Wanita \\
\hline SMKN 1 Trowulan & DIV (SST.Par ) & 5 - 10 tahun & PNS & Belum & Wanita \\
\hline
\end{tabular}




\begin{tabular}{|c|c|c|c|c|c|}
\hline Asal Sekolah & Pendidikan & $\begin{array}{c}\text { Lama } \\
\text { Bekerja }\end{array}$ & $\begin{array}{c}\text { status } \\
\text { pekerjaan }\end{array}$ & $\begin{array}{c}\text { Sertifikasi } \\
\text { Guru }\end{array}$ & $\begin{array}{c}\text { Jenis } \\
\text { kelamin }\end{array}$ \\
\hline SMKN 1 Singaraja & $\mathrm{S} 1$ (S.Pd ) & $>10$ tahun & PNS & Sudah & Wanita \\
\hline SMKN 1 Praya & DIV (SST.Par) & $5-10$ tahun & PNS & Sudah & Pria \\
\hline SMKN 2 Mataram & DIV (SST.Par) & $5-10$ tahun & PNS & Sudah & Pria \\
\hline SMKN 4 Mataram & $\mathrm{S} 1(\mathrm{~S} . \mathrm{Pd})$ & $5-10$ tahun & PNS & Belum & Wanita \\
\hline SMKN 1 Bima & S1 (S.Pd ) & $>10$ tahun & PNS & Sudah & Pria \\
\hline SMKN 1 Kupang & $\mathrm{S} 1(\mathrm{~S} . \mathrm{Pd})$ & $5-10$ tahun & $\begin{array}{l}\text { guru } \\
\text { honorer/GHS/ } \\
\text { GTT }\end{array}$ & Belum & Wanita \\
\hline SMKN 4 Makasar & S2 (M.Par) & $>10$ tahun & PNS & Sudah & Pria \\
\hline SMKN 1 Limboto & $\mathrm{S} 1(\mathrm{~S} . \mathrm{Pd})$ & $5-10$ tahun & PNS & Sudah & Pria \\
\hline SMKN 1 Gorontalo & $\begin{array}{l}\text { DIV (SST.Par ) } \\
\text { S2 (M.Pd) }\end{array}$ & $5-10$ tahun & PNS & Sudah & Wanita \\
\hline SMKN 1 Gorontalo & $\mathrm{S} 1$ (S.Pd ) & $5-10$ tahun & PNS & Sudah & Wanita \\
\hline SMKN 1 Ternate & $\mathrm{S} 1(\mathrm{~S} . \mathrm{Pd})$ & $<5$ tahun & $\begin{array}{l}\text { guru } \\
\text { honorer/GHS/ } \\
\text { GTT }\end{array}$ & Belum & Wanita \\
\hline SMKN 1 Toli toli & S1 (S.Pd ) & $5-10$ tahun & PNS & Sudah & Wanita \\
\hline SMKN 3 Singkawang & $\mathrm{S} 1(\mathrm{~S} . \mathrm{Pd})$ & $5-10$ tahun & PNS & Sudah & Wanita \\
\hline
\end{tabular}

Appendix $b$.

\section{Daftar Narasumber Ahli}

\begin{tabular}{|c|c|c|c|c|c|c|}
\hline Kode & $\begin{array}{c}\text { Jenis } \\
\text { kelamin }\end{array}$ & Usia & $\begin{array}{c}\text { Latar } \\
\text { Belakang } \\
\text { Pendidikan } \\
\end{array}$ & $\begin{array}{c}\text { Lama } \\
\text { bekerja }\end{array}$ & Posisi Pekerjaan & $\begin{array}{c}\text { Perusahaan/lembaga } \\
\text { tempat bekerja }\end{array}$ \\
\hline V.1 & Laki - Laki & 43 & $\begin{array}{l}\text { Sarjana } \\
\text { Pariwisata }\end{array}$ & 15 & Pemilik Perusahaan & $\begin{array}{l}\text { Visitama Travel and PCO, } \\
\text { Bandung }\end{array}$ \\
\hline V.2 & Laki - Laki & 37 & $\begin{array}{l}\text { Sarjana } \\
\text { Sosial }\end{array}$ & 13 & $\begin{array}{l}\text { Supervisor event } \\
\text { casual leasing (venue) }\end{array}$ & Trans Studio Casual Leasing \\
\hline V.3 & Perempuan & 53 & $\begin{array}{l}\text { Magister } \\
\text { (kandidat } \\
\text { doktor) }\end{array}$ & 20 & $\begin{array}{l}\text { Widyaiswara Usaha } \\
\text { Perjalanan } \\
\text { Wisata/Manager LSP } \\
\text { P2 }\end{array}$ & $\begin{array}{l}\text { PPPPTK Bisnis dan } \\
\text { Pariwisata }\end{array}$ \\
\hline V.4 & Perempuan & 39 & Doktor & 15 & Kepala Seksi Program & $\begin{array}{l}\text { PPPPTK Bisnis dan } \\
\text { Pariwisata }\end{array}$ \\
\hline V.5 & Laki - Laki & 37 & Doktor & 10 & Dosen & Politeknik Bandung \\
\hline
\end{tabular}

